\title{
THE EXISTENCE OF JUSTICE COLLABORATOR IN FASTENING THE ERADICATION OF CORRUPTION CRIME IN INDONESIA
}

\author{
Rohmadi $^{1}$, Supanto ${ }^{1}$, Hari Purwadi ${ }^{1}$ \\ ${ }^{1}$ Universitas Sebelas Maret \\ ABSTRACT
}

The aim of this reseach is to know the the existence of Justice Collaborator in Fastening the Handling of Corruption Crime in Indonesia. corruption is an extraordinary crime that requires careful and ongoing handling. Opportunities that can be maximized are using justice collaborators. Its existence is seen as being able to reveal the corruption network, thus completing its eradication. This research is normative, that uses evaluative research approach which is used to evaluate the regulation related to anti corruption and justice collaborator in Indonesia. The result of this research shows that the role of justice collaborator in criminal justice to eradicate corruption in Indonesia becomes very important, and needed a law and regulation for the Justice Collaborators as an effort to create a conducive climate and create a sense of secure for a person who wants to be a justice collaborator in the revealing of corruption criminal act.

Keywords: Corruption, Fastening, Eradication, Justice Collabolator

\section{A. Research Background}

Corruption is a kind of scourge for every people all around the world. Corruption which has deeply rooted will bring a consequence of an obstruction of the development in a country. The unsuccessful government in eradicating corruption will further weaken the government's image in the eyes of society. In the administration of government which is reflected in the form of society's distrust, society's disobedient to law, and the increasing of poverty rate in Indonesia.

Eradicating and proofing the happened of corruption crime is not as easy as turning over the hand. Corruption crime can be revealed after taking place for long period. Corruption crime generally involves a group of people who enjoy the advantage of this corruption crime. The concern about their involvement as the suspects will make them to cover each other. Thus consciously or unconsciously, corruption crime is done in an organized manner in their work environment. Corruption crime is a kind of crime which is hardly to be eradicated because the doers of this corruption crime usually have strong economic and political position, so that corruption crime is classified as "white collar crime, crimes as business, economic crimes, official crime and abuse of power.

According to Junaidi Soewartojo ${ }^{1}$, the expand of corruption practice in developing countries creates an image that the word of corruption may a word which is mostly cursed by people. Even there has emerge an expression that in most developing countries, corruption is a characteristic which is difficult to be eradicated. Historical fact actually proofs that not only a few countries have collapsed because one of the primary cause is corruption, but there are also more countries are able to come out from a corruption crisis.

Various crimes with increasingly sophisticated modus operandi, have been carried out either individually or in a neatly organized, meanwhile the development of criminal justice system is not in tune with the development of the crimes. The criminal justice system sometimes is slow and unready in anticipating the pace and the development of various crimes with changing modes. Thus,

\footnotetext{
1 Junaidi Soewartojo, Korupsi Pola Kegiatan dan Penindakannya serta Peran Pengawasan dalam Penanggulangan, Balai Pustaka, Jakarta, 1987, page 25.
} 
it seems necessary the presence of renewal in arranging the criminal justice system so it is able to anticipate various modes of the crimes that happened. The success of a process of criminal justice is strongly depended on the revealed or proofed evidence in the justice process especially which is related to the witnesses. $^{2}$

One thing which has been drawing attention is the appearance of some terms, Whistle Blower (WB) and Justice Collaborator (JC). ${ }^{3}$ Although these terms have been known for long time and used in some countries, in Indonesia these terms are still relative new in the criminal law reference. Nevertheless, Whistle Blower (WB) and Justice Collaborator (JB) now are getting more places in various scientific meeting even in law enforcement world remembering that their existence has given a new nuance in the criminal justice system. From some experiences in the countries which have adopted them, the presence of WB and JC has helped the criminal justice system in disassembling and revealing various organized crimes.

In the Form Letter of the Supreme Court (SEMA) Number 4 Year 2011 on the Treatment to Whistle Blower of Crime (Whistle Blower) and Justice Collaborator in a certain Criminal Case, whistle blower is a party who knows and reports a certain criminal case and not a part of the perpetrator he has reported. Whereas justice collaborator is a perpetrator of a certain criminal case, acknowledging something he has done, not the main actor on this crime an giving some information as a witness in the justice process.

\footnotetext{
2 Nandang Sambas and Dian Andriasari, "Telaah Kritis terhadap Perlindungan Saksi dan Korban Kejahatan dalam Sistem Peradilan Pidana di Indonesia", The paper was delivered on the Call for Paper Simposium MAHUPIKI date $18^{\text {th }}-19^{\text {th }}$ March 2013 in UNHAS Makasar.

${ }^{3}$ The Form Letter of the Supreme Court (SEMA) Number 4 Year 2011, Justice Collaborator is on of the perpetrator of a
}

The term of Justice Collaborator is known from the result of revolutionary effort in criminal law enforcement practice which is an impact of criminal modes development in Indonesia. Which then its existence gets some attention and begins to be regulated in Positive Law. The regulation of Justice Collaborator or perpetrator witness who cooperates is something new.

The reporting of this matter becomes a joy for the effort in law enforcement, especially for the eradication of corruption, the status granting of Justice Collaborator usually is given for a crime which is organized and causing serious threat to the society's security problem and overthrowing democracy values, especially in corruption crime action.

But until now, there are not any regulations which are in particular regulate the justice collaborator in Indonesia. Its regulation is implicitly contained in Act Number 13 Year 2006 on the Protection of Witness and Victim. The other regulation is the Form Letter of the Supreme Court (SEMA) Number 4 Year 2011 on Treatment for Whistle Blower of Crime (Whistle Blower) and Justice Collaborator. ${ }^{4}$ On the implementation, both the regulations are still far from the expectations in order to be able to protect the existence of justice collaborator in Indonesia.

Based on the above explanation, the problem which is going to be studied is how is the existence of Justice Collaborator in Fastening the Handling of Corruption Crime in Indonesia.

\section{B. Research Method}

certain criminal act, admitting something he has done, not the main perpetrator at this crime and giving some testimony as a witness in the trial process.

${ }^{4}$ Abdul Haris Semendawai, et.al, Memahami Whistleblower. Lembaga Perlindungan Saksi dan Korban (LPSK), December 2011, page $X$. 
Research method used by the writer is evaluative research approach which is used when someone is going to assess the program being run and perspective research approach that is a research to obtain some recommendations on something should be done to eradicate certain problems. This nature of research is an exploratory research with Statute Approach and Case Approach. This study uses literature study in collecting research data sources.

\section{Result of the Study and Discussion}

\section{The Existence of Justice Collaborator in} Fastening the Handling of Corruption

\section{Criminal Case in Indonesia}

The meaning of Justice Collaborator based on the Form Letter of the Supreme Court (SEMA) Number 4 Year 2011 on Treatment for Whistle Blower of Crime (Whistle Blower) and Justice Collaborator is doer of a certain criminal case, but not the main doer who confessing his action and willing to be a witness in the judicial process. ${ }^{5}$

The basic concept of Justice Collaborator is a joint effort to find a truth in order to reveal justice which will be delivered to the society. From this truth finding together, the context of Justice Collaborator is in two diametrically contradictory sides: law enforcer and law breaker ${ }^{6}$. There are some requirements to become a Justice Collaborator, including the doer is not the main doer in his case, he restores some obtained asset, the given information should be clear and having correlation which is valued worthy to be followed up.

Justice collaborator aims to facilitate verification and prosecution and able to completely reveal a certain criminal case especially related to criminal organization. At

\footnotetext{
5 SEMA Number 4 Year 2011 on The Treatment for the Whistle blower and Justice Collaborator.

6 Andang Sambas and Dian Andriasari, "Telaan Kritis terhadap Perlindungan Saksi dan Korban Kejahatan dalam
}

this context, corruption case in Indonesia is never done individually but collectively. The existence of justice collaboration provision becomes a legal loophole which is expected capable in strengthening evidence collection in the trial.

In Indonesia, the development of Justice Collaborator idea actually has starting point at the Provision of Article 37 (2) of the United Nations Convention Against Corruption (UNCAC) Year 2003 which is adopted by the $58^{\text {th }}$ Trial of General Assembly through Resolution Number 58/ 4 date $31^{\text {st }}$ October 2003 which is also ratified through Act Number 7 Year 2006 on the Ratification of the United Nations Convention Against Corruption which effectively applied since $18^{\text {th }}$ April 2006 where it is confirmed that, "every participating country has to take into account, give some possibilities in certain cases, give punishment to a doer who giving substantial cooperation in the investigation or prosecution of a crime which is set in this convention".

Besides UNCAC, Indonesia has also ratified the United Nations Convention Against Transnational Organized Crime through Act Number 5 Year 2009 on the United Nations Convention Against Transnational Organized Crime (UNCATOC). These two United Nations' Convention are the basic legal which become the background the emergence of idea on Justice Collaborator in criminal justice system in Indonesia.

In the disclosure of a criminal case, from the investigation level, charging level, until trial level, the role of a witness is extremely important and often becomes the determinant in the disclosure of a case. Almost no criminal case in its proving process

Sistem Peradilan Pidana di Indonesia", The paper is delivered on the Call for Paper Simposium MAHUPIKI date $18^{\text {th }}-19^{\text {th }}$ March 2013 in UNHAS Makassar. 
does not use witness' testimony evidence because witness' testimony is the most importance evidence in proving a criminal case. As well as regulated in Article 184 KUHAP which states that the valid evidence consists of : a. Witness' testimony, b. Expert's testimony, c. Letter, d. Clues, e. Defendant's statement.

The role of witness in every criminal case trial is extremely important because witness' testimony can influence and determine the tendency of judge's decision. In a criminal judicial process, law enforcer apparatus often experience some difficulties in revealing a criminal case because the absence of witness who has seen, heard or experienced by himself a certain criminal case as the result of witness' unwillingness to give any information with security reasons, likes currently especially in extra ordinary criminal case such as corruption, where almost all big cases of corruption are difficult to be revealed. Because likes what has been known that corruption case in Indonesia is never carried out by individual but collective, justice collaborator becomes a legal loophole which is expected capable in strengthening the collecting process of evidence in the trial.

Therefore, the use of justice collaborator in criminal trial becomes extremely important and is a form of an extraordinary effort which can be used to facilitate in eradicating a criminal act which belongs to extraordinary crime. ${ }^{7}$ Extraordinary crime category for a perpetrator of a criminal act obviously need some extraordinary measures/ extraordinary enforcement. Therefore, legal protection is extremely needed by the whistle blower of an activity against the law. Essentially, the presence of justice collaborator is aimed to a very serious crime which needs immediate handling. The thing which is done by a justice collaborator is used to attract public attention. With this public attention, it is expected that the public realize the danger level of the leaked crime, therefore this crime or offense can be stopped. But generally, people are unwilling or afraid for becoming the reporting witness or perpetrator witness who cooperate, because the risk they will face is very big and dangerous, even though their statement or testimony can reveal a criminal act which is harmful for the Country and public interests. Without the presence of incentives and clear and adequate legal protection, it will not trigger the emergence of witness who is willing to cooperate, therefore some cases which are detrimental to the state or related to public interest which has difficulties in its disclosure will be difficult to be revealed.

Justice Collaborator has great opportunity, remembering it strategic role in revealing an organized corruption criminal act web. A step which is taken by the government currently is by making some revision on the protection to witness and victim by adding some provisions which regulate Justice Collaborator. The use of Justice Collaborator in criminal justice is a form of extraordinary effort which can be used to eradicate corruption criminal act which involves the perpetrator of the criminal act it self, where the perpetrator is willing to cooperate with the law enforcer apparatus. The role of witness as justice collaborator is very important in the process of corruption criminal act eradication.

SEMA (the Form Letter of the Supreme Court) Number 4 Year 2011 has regulated one of the evidence that is witness' testimony evidence. Where the mention of witness in this Form Letter of the Supreme

\footnotetext{
7 Zhulfiana Pratiwi Hafid (2019) Justice Collaborator reviewed from Act Number 31 Year 2014 on the Protection to Witness and Victim: Al-Qadau Journal.
} 
Court is perpetrator witness in the Form Letter of the Supreme Court of RI Number 4 Year 2011 on the Treatment to the Whistle Blower of a Criminal Act and the cooperating Perpetrator Witness (justice collaborator) in a certain criminal case is that the person is a doer of a certain criminal act as well as referred in the Form Letter of the Supreme Court, admitting the crime he has committed, not the main perpetrator at this crime and giving testimony as the witness in the trial process. According to Azis Syamsuddin ${ }^{8}$, based on lex spesialis derogate lex generali principle (special provision defeats general provision), therefore the Form Letter of the Supreme Court can be used as a guide for the judges in handling some cases which involves justice collaborator.

Various crimes with increasing sophisticated modus operandi are carried out neatly either individually or collaboratively, whereas the development of criminal justice system in Indonesia is not in tune withe the development of the crimes themself ${ }^{9}$. The number of cases which have ran aground halfway because of the absence of accuracy of testimony and information from the victim or witness therefore it is not able to sustain the job of law enforcer in the trial process. However, some facts still indicate that witness and victim protection in the criminal justice process legally still has not obtained an adequate attention. People's reluctance who are experiencing or knowing a criminal act to become a witness because of the absence of an adequate legal protection guarantee, especially upon a certain guarantee and a certain mechanism to testify because these witnesses often get intimidation, criminalization, and lawsuits upon their

\footnotetext{
${ }^{8}$ Azis Syamsuddin, Special Crimes (Jakarta: SInar Grafika, 2011), p. 11.

${ }^{9}$ Rusli Muhammad (2015), The Arrangement and Urgency of Whistle Blower and Justice Collaborator in Criminal Justice System: Legal Journal IUS QUIA IUSTUM NO. 2 VOL. 22.
}

testimony or statement they have given and finally they become the suspects, the defendants and even the convicts.

There has been recorded some cases which use the role of justice collaborator, such as corruption case which is handled by KPK (Corruption Eradication Commission), at least there are two persons who has been called as justice collaborator that is ex member of the House of Representatives from PDIP fraction, Agus Condro Prayitno, who has been found guilty receiving bribe related to the election of Senior Governor Deputy of Bank of Indonesia (DGSBI) year 2004. Agus Condro has gotten parole since the late of October 2013.

The second case which involves ex Marketing Director of PT Anak Negeri, Mindo Rosalina Manulang, has also gotten justice collaborator label. Rosa herself has been convicted because buying off Sesmenpora Wafid Muharram in athlete guesthouse development in Palembang.

Next still in 2013, a breakthrough has done by the Supreme Court Judge, Dr. Artidjo Alkostar, Prof. Dr. Surya Djaya and Sri Mulyani in the decision No: 920K/Pid.sus/2013, which has handed down a light sentence to Thomas Claudius Ali Junaidi, the cases justice collaborator in this case.

However, the role of justice collaborator in Indonesia is rated very low. Based on the data of LPSK from 2010 - 2019 period, the protected LPKS which has status as justice collaborator is only 15 persons. ${ }^{10} \mathrm{It}$ proves that the government has not been optimal in applying the role of justice collaborator, plus the unclear regulation on the justice collaborator. It increasingly makes the doer who wants to be a justice collaborator

10 Kompas.com (2019), LPSK Nilai Peran “Justice Collaborator" Kasus Korupsi Belum Optimal, accessed on $25^{\text {th }}$ November 2019. 
discourage because he assesses there are many threats which will be faced then. In this case, the role of government is giving a binding and clear protection on this matter in order that the doer who wants to become the justice collaborator increase in number. Based on this matter, the role of justice collaborator in the disclosure of organized criminal act needs a regulation which regulates the justice collaborator to reveal and expose corruption criminal act. However, some problem faced currently in Indonesia that the arrangement of justice collaborator has not been regulated in KUHP. In the KUHAP it is only regulated on the rights of a doer in the criminal judicial process, as well as Act Number 31 Year 2014 on the Protection of Witness and Victim. ${ }^{11}$ On the other hand, although justice collaborator has been regulated explicitly in SEMA Number 4 year 2011, but it has not been regulated in a binding manner and clearly on the protection of justice collaborator.

Protection to justice collaborator in Indonesia still becomes a controversial problem because on the one hand, spirit to protect witness and victim is extremely high and on the other hand, the provision of regulation which regulates the protection to justice collaborator has not been adequate. Then, in order to optimize the role of justice collaborator in the disclosure of corruption case in Indonesia, the government has to make a clear regulation and also equating the definition of justice collaborator which is still considered different.

As a citizen who is knowing how dangerous is the corruption criminal act has an important role in facilitating the law enforcer institution in revealing a criminal case through the role of a justice collaborator to be capable

\footnotetext{
${ }^{11}$ Act of Republic of Indonesia Number 31 Year 2014 on the Protection to Witness and Victim.

12 Zhulfiana Pratiwi Hafid (2019), Justice Collaborator reviewed from Act Number 31 Year 2014 on the Protection to Witness and Victim: Al-Qadau Journal.
}

in helping and cooperating with the law enforcer in disclose the scandal of corruption case which involves himself, the involvement of justice collaborator can help the law enforcer to reveal a big case, so that indirectly it will give positive impact to the condition of our criminal judicial system which experiencing any difficulties in dragging the perpetrators of corruption criminal act in to the trial and also punishing the perpetrators as a form of accountability upon something they have done.

Justice collaborator itself has an extremely dominant role in helping the law enforcer apparatus to disclose and reveal a criminal act. It is because a justice collaborator is a person who has role in the occurrence of an organized criminal act which is done collectively. ${ }^{12}$ However, position of a justice collaborator is not the main perpetrator, but only the minor perpetrator. This justice collaborator then can be used as a source of information in relation to reveal the main offender so that the crime can be completely revealed and does not stopped only on the perpetrator who has minimal role in this crime.

The complexity of the problem in uncovering corruption criminal act case makes the government should takes a new breakthrough which is considered more effective in eradicating all kinds of crime especially in corruption crime act. ${ }^{13} \mathrm{By}$ making the role of justice collaborator active, it will facilitate in the proof and prosecution and can completely reveal a criminal act especially which is related to criminal organization, at this context, corruption case in Indonesia is never done individually but collectively. The existence of provision on

\footnotetext{
13 Fadli Razeb Sanjani (2015), The Application of Justice Collaborator in Criminal System in Indonesia: Online Journal of Law Faculty Student of Universitas Riau.
} 
justice collaborator is a form of legal loophole which is expected can strengthen the collecting of evidence in the trial.

\section{Conclusion}

The many cases of corruption in Indonesia indicates that the not optimal handling of corruption criminal act, at this matter the use of justice collaborator in criminal justice is one of extraordinary efforts which can be used to eradicate corruption criminal act. The role of justice collaborator in criminal justice becomes very important and is a form of effort which can be used to help in fastening the handling of corruption criminal act in Indonesia. There will be needed a law and regulation for the Justice Collaborators as an effort to create a conducive climate and create a sense of secure for a person who wants to be a justice collaborator in the revealing of corruption criminal act.

\section{REFERENCES}

1. Abdul Haris Semendawai, et.al, Memahami Whistleblower. Lembaga Perlindungan Saksi dan Korban (LPSK), December 2011

2. Andang Sambas and Dian Andriasari, "Telaan Kritis terhadap Perlindungan Saksi dan Korban Kejahatan dalam Sistem Peradilan Pidana di Indonesia”, The paper is delivered on the Call for Paper Simposium MAHUPIKI date $18^{\text {th }}-19^{\text {th }}$ March 2013 in UNHAS Makassar.

3. Azis Syamsuddin, Special Crimes, Jakarta: SInar Grafika, 2011

4. Act of Republic of Indonesia Number 31 Year 2014 on the Protection to Witness and Victim.
5. Fadli Razeb Sanjani (2015), The Application of Justice Collaborator in Criminal System in Indonesia: Online Journal of Law Faculty Student of Universitas Riau.

6. Junaidi Soewartojo, Korupsi Pola Kegiatan dan Penindakannya serta Peran Pengawasan dalam Penanggulangan, Balai Pustaka, Jakarta, 1987

7. Kompas.com (2019), LPSK Nilai Peran “Justice Collaborator" Kasus Korupsi Belum Optimal, accessed on $25^{\text {th }}$ November 2019.

8. Nandang Sambas and Dian Andriasari, "Telaah Kritis terhadap Perlindungan Saksi dan Korban Kejahatan dalam Sistem Peradilan Pidana di Indonesia", The paper was delivered on the Call for Paper Simposium MAHUPIKI date $18^{\text {th }}-19^{\text {th }}$ March 2013 in UNHAS Makasar.

9. Rusli Muhammad (2015), The Arrangement and Urgency of Whistle Blower and Justice Collaborator in Criminal Justice System: Legal Journal IUS QUIA IUSTUM NO. 2 VOL. 22.

10. SEMA Number 4 Year 2011 on The Treatment for the Whistle blower and Justice Collaborator.

11. The Form Letter of the Supreme Court (SEMA) Number 4 Year 2011, Justice Collaborator is on of the perpetrator of a certain criminal act, admitting something 
he has done, not the main perpetrator at this crime and giving some testimony as a witness in the trial process.
12. Zhulfiana Pratiwi Hafid (2019) Justice Collaborator reviewed from Act Number 31 Year 2014 on the Protection to Witness and Victim: Al-Qadau Journal. 